\title{
Alstrom's syndrome: further evidence of autosomal recessive inheritance and endocrinological dysfunction
}

\author{
S J Charles, A T Moore, J R W Yates, T Green, P Clark
}

\begin{abstract}
We report a case of Alstrom's syndrome with hypothyroidism in addition to the cardinal features of blindness, deafness, obesity, and insulin dependent diabetes mellitus. The parents were first cousins once removed which strengthens the case for autosomal recessive inheritance.
\end{abstract}

Alstrom's syndrome was first described in 1959 as a combination of atypical retinal pigmentary degeneration, obesity, diabetes mellitus, sensorineural deafness, and normal intelligence. ${ }^{1}$ Further cases have been described and the constellation of signs now recognised as part of the syndrome includes acanthosis nigricans, male hypogenitalism, hyperuricaemia, hypertriglyceridaemia, baldness, kyphosis, and renal dysfunction. ${ }^{2-4}$ Renal disease is a late manifestation and renal failure is a cause of death in some patients. Hypothyroidism has not previously been described in Alstrom's syndrome.

\section{Case report}

The patient was the youngest in a sibship of three girls. Her parents were first cousins once removed (fig 1). The common ancestors were not known to be of Scandinavian extraction. She was noted to have poor

Department of Ophthalmology, Addenbrooke's Hospital, Hills Road, Cambridge CB2 2 QQ.

S J Charles, A T Moore

Department of Clinical Genetics, Addenbrooke's Hospital, Cambridge.

J R W Yates

Department of Dermatology, Addenbrooke's Hospital, Cambridge.

T Green

Department of Clinical Biochemistry, Addenbrooke's Hospital, Cambridge.

P Clark

Correspondence to Mr Charles.

Received for publication 8 February 1990.

Accepted for publication 8 March 1990. vision from early childhood with photophobia and nystagmus, and attended a school for the blind from the age of 5 years. She was of short stature and obese. Hearing was poor from the age of 10 and bilateral hearing aids were worn from the age of 12 . Dark areas of skin in the axillae and groin were noted at 13 years of age, and over the teenage years she developed thickened pads on the knees and elbows. When aged 22 , glycosuria was noted and a glucose tolerance test showed a diabetic profile. She was initially controlled on diet alone but later required oral hypoglycaemic agents. At 23 years she complained of persistent fatigue together with a dry skin and was found to be hypothyroid: T4 $52 \mathrm{nmol} / 1(65-140)$, free T4 $8 \cdot 1$ $\mathrm{pmol} / \mathrm{l}(9-23)$. A TRH test $(200 \mu \mathrm{g})$ showed a basal TSH of $4 \mathrm{mU} / 1(0.4-4 \cdot 0)$ with an exaggerated TSH response at 20 minutes $(40 \mathrm{mU} / \mathrm{l})$ and at 60 minutes (34 mU/l), compatible with secondary hypothyroidism owing to a hypothalamic or pituitary defect. She was

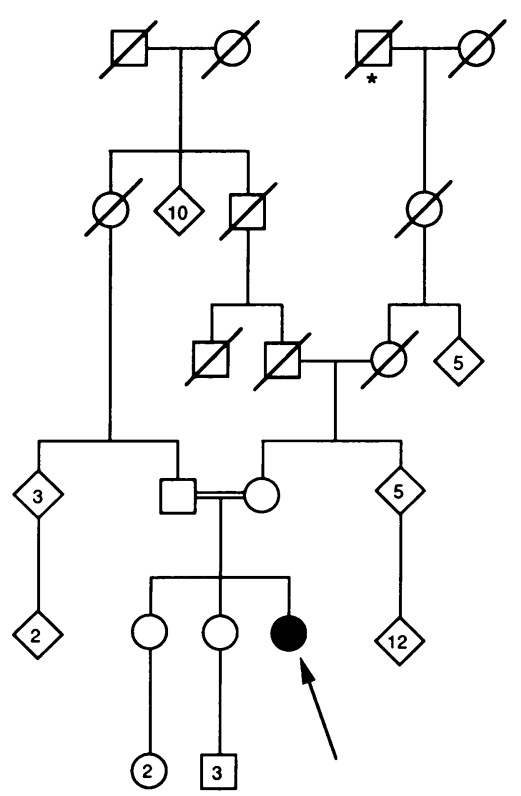

Figure 1 Pedigree showing consanguinity. The common ancestors were not known to be of Scandinavian extraction but another great great grandparent (*) came from Norway. 
started on thyroxine replacement and is now controlled on $100 \mu \mathrm{g}$ of thyroxine daily. Antithyroid microsomal and thyroglobulin antibodies were not detected. From the age of 24 she had recurrent urinary tract infections associated with a tight urethral stenosis treated by dilatation, and later developed incontinence necessitating an indwelling urinary catheter. Urodynamic studies have shown a large capacity bladder with diminished sensation and detrusor instability, but with no vesicoureteric reflux (as seen in the BardetBiedl syndrome). It was thought her problems resulted from a sensory neuropathy although there were no other features suggestive of diabetic neuropathy.

\section{EXAMINATION}

On latest review, at the age of 27 years, she was short (height $145 \mathrm{~cm}$, below the 3rd centile; father's height $170.5 \mathrm{~cm}, 25$ th centile; mother's height $166 \mathrm{~cm}, 75$ th centile) and weighed $60.5 \mathrm{~kg}$ (above the 50th centile). Head circumference was 1 SD above the mean. She had a short neck, broad shoulders and trunk, and small hips with a kyphoscoliosis (fig 2). Histologically proven acanthosis nigricans was present in the axillae and groin and there were elbow and knee pads; there was no hirsutism. Intelligence was normal. Pelvic examination showed a small uterus with no adnexal masses. Ophthalmic examination showed nystagmus

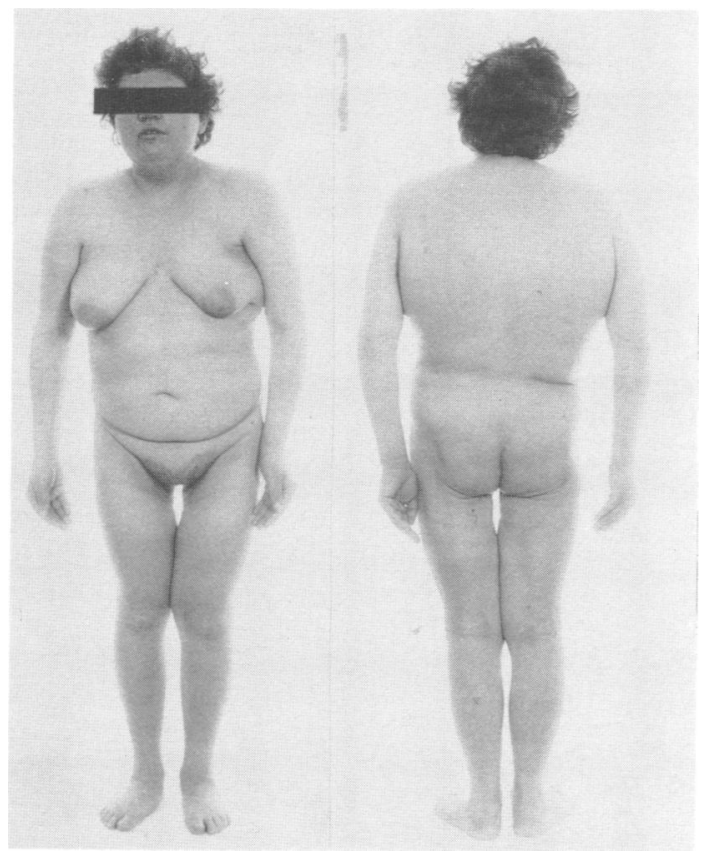

Figure 2 Photographs of the patient showing obesity, and broad shoulders and trunk with small hips. and photophobia with no perception of light in each eye. There were bilateral posterior subcapsular lens opacities, atrophic discs, attenuated retinal vessels, and marked thinning of the retinal pigment epithelium, but without typical bone corpuscle pigmentation.

\section{INVESTIGATIONS}

The patient had no recordable electroretinogram (ERG). Audiometry showed profound sensorineural hearing loss. Chromosomal analysis showed a normal female karyotype. Glucose tolerance testing showed a basal hyperinsulinaemia $(193 \mathrm{pmol} / \mathrm{l}$, normal $<60$ $\mathrm{pmol} / \mathrm{l})$ and basal hyperproinsulinaemia $(23 \mathrm{pmol} / \mathrm{l}$, normal $<10 \mathrm{mmol} / \mathrm{l})$ in the presence of a normal fasting glucose $(5 \cdot 8 \mathrm{mmol} / \mathrm{l})$. After the glucose load $(75 \mathrm{~g})$, insulin concentrations rose slowly to a maximum of $465 \mathrm{pmol} / \mathrm{l}$ at 90 minutes, whereas glucose rose to $19.3 \mathrm{mmol} / \mathrm{l}$ and $19.4 \mathrm{mmol} / \mathrm{l}$ at 90 and 120 minutes, respectively. Antibodies against insulin receptors were not detected. Fasting hypertriglyceridaemia $(2.7 \mathrm{mmol} / \mathrm{l})$ was present but other lipids were within the normal range and there was no hyperuricaemia. Serum FSH, LH, oestradiol, testosterone, dihydroepiandrostenedione (DHEAS), and androstenedione were within normal limits. There was evidence of renal impairment: glomerular filtration rate was reduced $(49 \mathrm{ml} / \mathrm{min})$, with albuminuria. Pelvic and abdominal ultrasound were normal.

Radiological skeletal survey showed hyperostosis frontalis interna, squared iliac bones, and increased angulation of both femoral heads.

The parents had no eye complaints or hearing loss and had normal visual acuity and ocular examination. ERG showed normal rod and cone responses, and audiometry and glucose tolerance testing were also normal in both parents.

\section{Discussion}

The presence of blindness from an early age with a retinal dystrophy, profound sensorineural deafness, obesity, diabetes mellitus, and acanthosis nigricans led to the diagnosis of Alstrom's syndrome. BardetBiedl syndrome was excluded because of the normal intelligence and absence of polydactyly. Alstrom's syndrome is presumed to be autosomal recessive but in oniy two families has there been definite evidence of consanguinity, albeit comparatively distant: third cousins in one case ${ }^{1}$ and fifth cousins in the other. ${ }^{2}$ In the family reported here the parents were first cousins once removed lending further support for autosomal recessive inheritance. Alstrom suggested that carriers have abnormalities of hearing and glucose tolerance, ${ }^{1}$ but this was not found in the parents of this case.

Insulin resistant diabetes mellitus may be the result of inadequate binding of insulin to its receptors or failure of insulin to initiate the normal post-receptoral 
changes necessary for insulin action.' Reduced binding may result from antireceptor antibodies or an intrinsic abnormality of the receptor itself. Both mechanisms have been demonstrated in patients with insulin resistance and acanthosis nigricans. ${ }^{6}$ The absence of antireceptor antibodies in our patient suggests that in Alstrom's syndrome the defect lies in the insulin receptor or the post-receptoral pathway initiating the cellular response. Rudiger $e t a l^{7}$ have shown normal insulin receptor binding and normal insulin mediated RNA synthesis in cultured fibroblasts from two patients with Alstrom's syndrome, so the exact mechanism of insulin resistance remains unclear. The hypothyroidism in our patient appeared to result from a central pituitary or hypothalamic defect, since TSH was normal in the presence of low $\mathrm{T} 4$ and these patients may rarely have an exaggerated TSH response. ${ }^{8}$ In addition to insulin resistance, target organ unresponsiveness to vasopressin and gonadotrophins have also been reported, ${ }^{3}$ and therefore the presence of hypothyroidism in this case adds further evidence for a widespread abnormality of hormone receptors in this disorder.
The authors would like to thank Professor B Jay, Dr D Guttman, and Dr A P Weetman for their helpful discussions about this case.

1 Alstrom $\mathrm{CH}$, Hallgren $\mathrm{B}$, Nilsson LB, Asander $\mathrm{H}$. Retinal degeneration combined with obesity, diabetes mellitus and neurogenous deafness. Acta Psychiatr Neurol Scand 1959;34 (suppl 129):1-35.

2 Klein D, Ammann F. The syndrome of Laurence-Moon-BardetBiedl and allied diseases in Switzerland. Clinical, genetic and epidemiological studies. F Neurol Sci 1969;9:479-513.

3 Goldstein JL, Fialkow PJ. The Alstrom syndrome. Report of three cases with further delineation of the clinical, pathophysical and genetic aspects of the disorder. Medicine (Baltimore) 1973;52:53-71.

4 Millay RH, Webeler RG, Heckenlively JR. Ophthalmologic and systemic manifestations of Alstrom's disease. Am f Ophthalmol 1986;102:482-90.

5 Kahn CR, Goldstein BJ. Molecular defects in insulin action. Science 1989;245:13.

6 Kahn RC, Flier JS, Bar RS, et al. The syndromes of insulin resistance and acanthosis nigricans. $N$ Engl f Med 1976;294: $739-45$.

7 Rudiger HW, Ahrens P, Dreyer M, et al. Impaired insulininduced RNA synthesis secondary to a genetically defective insulin receptor. Hum Genet 1985;69:76-8.

8 Pinchera A, Martino E, Faglia G. Central hypothyroidism. In: Ingbar SH, Braverman LE, eds. The thyroid. Philadelphia: Lippincott, 1986:1235-54. 